\title{
The Manitoba Centre for Health Policy: A Case Study
}

\section{Centre des politiques de santé du Manitoba : une étude de cas}

\author{
政 \\ GAIL MARCHESSAULT, PHD, PHEC, RD \\ Independent Qualitative Health Researcher \\ Winnipeg, $M B$
}

\begin{abstract}
Context: The Manitoba Centre for Health Policy (MCHP) is a university research centre with a long-standing contractual arrangement with government.

Objective: The purpose of this project was to examine the facilitators and challenges in the development, establishment and continuation of MCHP.

Methods: In-depth, semi-structured interviews with 28 participants selected purposefully and a document review were conducted and analyzed using qualitative methods.

Results: Although a unique confluence of factors facilitated MCHP's establishment, participants viewed safeguards to credibility (arm's-length from government; guaranteed academic freedom) along with powerful advocates as key to longevity. Other factors that participants discussed as important to sustainability included excellence in scholarship; thorough protection of privacy; stable funding; incremental growth; teamwork; leadership; nurturing of relationships; and authentic partnerships.

Conclusions: MCHP has demonstrated that using local administrative data to address policyrelated research questions is of enduring value to local and provincial communities, and also has national and international relevance.
\end{abstract}




\section{Résumé}

Contexte: Le Centre des politiques de santé du Manitoba (Manitoba Centre for Health Policy, $\mathrm{MCHP}$ ) est un centre de recherche universitaire qui compte sur une entente contractuelle à long terme avec le gouvernement.

Objectif : Le but de ce projet était d'examiner les facteurs facilitants et les défis liés au développement, à l'établissement et à la continuité du MCHP.

Méthodologie : Les renseignements recueillis par des entrevues semi-structurées en profondeur, menées auprès de 28 participants choisis expressément, et par une revue de documents ont été analysés au moyen de méthodes qualitatives.

Résultats: Bien qu'une confluence particulière de facteurs aient facilité l'établissement du MCHP, les participants estiment que la longévité du centre est tributaire de mesures de sauvegarde de sa crédibilité (autonomie face au gouvernement; garantie de la liberté de recherche) ainsi que de la présence de puissants porte-parole. Parmi les autres facteurs que les participants ont jugé importants pour la durabilité se trouvent l'excellence de la mission professorale, une protection rigoureuse de la confidentialité, un financement stable, une croissance incrémentielle, le travail d'équipe, le leadership, l'entretien des relations et la présence de partenariats authentiques. Conclusions: Le MCHP a démontré que l'utilisation des données administratives locales pour traiter les questions de recherche sur les politiques présente une valeur durable pour les communautés locales et provinciales et est également pertinente aux niveaux national et international.

He Manitoba Centre for Health Policy (MCHP; "the Centre") is a
research centre located in the Department of Community Health Sciences in the
University of Manitoba's Faculty of Medicine in Winnipeg, central Canada. Research scientists and their collaborators at the Centre study health services, population and public health and the social determinants of health using population-based data. Formally established in 1991 with funding from the Manitoba government, it maintains a strong focus on answering questions of interest to local policy makers. The Centre has had both an academic and a policy thrust from its first contract with Manitoba Health. It now has formal associations with five government departments and 11 regional health authorities (RHAs) to address research questions aimed at improving the health of Manitoba's citizens.

MCHP's success in research endeavours has attracted national and international attention as demonstrated by multiple speaking invitations and visitors wanting to learn more about the Centre (Martens 2008; MCHP 2007a,b, 2008). Previous papers on the Centre's use of administrative databases have been cited as often as 700 times (Lewis et al. 2009).

The purpose of this project was to examine the facilitators and challenges in the development, establishment and continuation of MCHP through documenting the perspectives of people involved with the Centre as it evolved. It adds further perspectives to previously published reports by MCHP investigators (Roos et al. 2007; Roos 1999; Roos and Shapiro 1995; Bowen et al. 2005). 


\section{Methods}

A case study is both a process for learning and a choice of object to be studied (Patton 2002). It is a useful approach when the research goal is to appreciate the uniqueness and complexity of an organization within its context (Baxter and Jack 2008; Stake 2005). I used qualitative methods, including a document review and semi-structured interviews.

\section{Document review}

I reviewed publicly available documents and in-house records (such as annual reports, newsletters, meeting minutes, external reviews and other materials) to inform and complement interview data.

\section{Individual interviews}

In-depth, semi-structured interviews were used because a major goal was to elicit participants' accounts of the Centre's development. Questions concerned each participant's role with MCHP, challenges encountered and how they were met, key issues, events, successes and failures, other influences and - as is usual in qualitative research - follow-up questions to clarify responses.

I selected participants purposefully from a list compiled with MCHP's executive management team, the founding directors and an early mentor, Evelyn Shapiro. The individuals named most frequently were associated with the Centre's formative years.

The response rate to interview invitations was 100\%. Eight of the 28 participants requested anonymity; the others explicitly agreed to mentioning their names. I interviewed the founding and current directors (3), a university department head, deans (2), a past president, a health minister, deputy ministers (3), advisory board chair and members (2), people associated with government (9), current (10) and former (4) MCHP staff (including support staff, data analysts and researchers) and others (2). Some participants had more than one role.

Interviews were audio-recorded and transcribed, and I solicited participant feedback on both records and, for some, on interview summaries prepared for a more extensive report available from MCHP (Marchessault 2010). Quotations have been edited to improve readability.

\section{Analysis}

Analysis involved reviewing transcripts, coding and categorizing text to identify topics and patterns that could be developed into themes, using $\mathrm{N}$-Vivo to assist with organizing data (version 8, QSR International Pty Ltd., Cambridge, MA 2009).

\section{Ethical approval}

The University of Manitoba Health Research Ethics Board provided ethical approval for this project.

\section{Results}

\section{Pre-Centre events}

Although the Centre was formally created in 1991, its story begins in 1973, after Drs. 
Leslie and Noralou Roos moved to Winnipeg to take positions in the business school at the University of Manitoba. Dr. Noralou Roos met Dr. Paul Henteleff, Assistant Executive Director of Health Services at the Manitoba Health Services Commission (MHSC) from 1972 to 1974, a meeting that led to the population approach to the study of healthcare in Manitoba. Dr. Roos discovered both the existence of the administrative health database, with physician and hospital billing claims for virtually all Manitobans, and an enthusiastic research collaborator. Dr. Henteleff suggested an investigation of physician visits and surgeries for tonsillectomy to evaluate against guidelines for medical care, and he facilitated access to the data.

Using computers for health research was a relatively new methodology; however, the Rooses had worked with them in the mid-1960s while completing their doctorate degrees in political science at the Massachusetts Institute of Technology. Manitoba's geography and relatively small size also facilitated this research. Records for both physician and hospital claims were held in one place by one organization. This endeavour helped build relationships and establish trust, a pre-condition for sharing personal health information concurrent with working out methods to protect confidentiality.

The tonsillectomy study was published (Roos et al. 1977a,b), and two years later a journalist's report, "End to Unneeded Surgery Sought" (Rubin 1979), got the attention of the Manitoba Legislature and the College of Physicians and Surgeons. This first research experience with MHSC data raised some important issues, such as access to data in a way that protects confidentiality but allows tracking of services to individuals; the impact of the media's presentation of research findings; and difficult relationships with physicians affected by research results who questioned the validity and relevance of the data. Centre researchers have worked to resolve these challenges, for example, by partnering with physicians to increase their receptivity to research results.

Many interviewees discussed the "terrific database" as fundamental to the Centre's success. Les Roos remarked that the Repository gave them a comparative advantage early on when competition was minimal. MCHP added data sources incrementally, going from three databases initially to about 10 when the Centre was established, to 90-plus at the 20th anniversary. "Start small and build slowly" was discussed as a success factor. Current linkages in such areas as education, social services and housing provide the ability to address many new research questions in population health. The data sets and the research scientists' innovative use of them provide the Centre's current comparative advantage.

Another early decision was to have all researchers use the same statistical analysis system (SAS), which permitted sharing of code among projects and over time. Documentation efforts such as the Concept Dictionary and Glossary (MCHP 2010) further facilitated sharing resources.

For the next 15 years, the Rooses obtained external funding to continue their research using anonymized extracted MHSC data. In the process, they pioneered a new way of doing health services research.

\section{Establishment of the Centre}

On August 3, 1990, Donald Orchard, then Minister of Health in Premier Gary Filmon's 
Progressive Conservative government, announced the creation of a \$3.5-million health research centre to be funded over three years (Campbell 1990). The expectation, stated within the contract, was that the Centre would become self-sustaining (Maynard and Naimark 1991: 3). As Noralou Roos pointed out, they had been self-sufficient and could easily continue to operate independently; however, if they were not funded they could not produce deliverables, the government-funded research projects.

Orchard is widely credited with making the Centre happen, and along with then-Deputy Minister of Health Frank Maynard, initiated the contacts that led to this long-lasting government-university partnership. Both said the primary factors behind their initiative were the government's need for information to make good policy decisions in a challenging fiscal and political climate, and learning of the relevance of the Rooses' work to filling this need. They highlighted the influence of Dr. Fraser Mustard, founder of the Canadian Institute for Advanced Research, in stimulating their interest in population health and for promoting a shared understanding about the potential of the proposed research centre through meetings with the premier and members of the Manitoba Cabinet.

University leaders Dr. Arnold Naimark, president of the University of Manitoba, Dr. John Wade, dean of the Faculty of Medicine and Dr. Brian Postl, head of the newly formed Department of Community Health Sciences, each highlighted the social context of the 1970s and 1980s as sparking their interest in population health and inspiring their support. They were receptive to the government's proposal despite its novelty and widespread concerns about academic freedom and possible perceptions of bias.

Maynard said the government shared these concerns because the value of the research rested on the Centre's credibility with the public. Consequently, the Centre was positioned within the university, and the role of government was limited to participating in choosing projects and assisting with fact-finding, with no right to influence the content of reports.

The advisory board was initially structured to protect academic needs while assuring the government that projects would be timely and relevant to decision-makers. Maynard and Noralou Roos co-chaired the board initially with membership including internationally renowned researchers and local representatives of government and the business community. This wide-ranging membership increased the Centre's visibility and enhanced its credibility. As the Centre's reputation grew, board membership shifted to reflect increased intergovernmental involvement, viewed as helpful in expanding the databases and promoting sustainability.

The first contract included the Centre's right to publish findings after 180 days (now 60 days), and several interviewees remarked that no government has tried to embargo a report or interfere with the interpretation of findings, even when results were unfavourable.

Because governments are often protective of their information sources, funding the Centre and having it outside the control of government was potentially risky. However, Orchard said there was nothing to fear from negative reports because informing the public about the evidence behind policy recommendations would increase support for needed change. He said, "We absolutely, on a number of issues, took the rat-pack politics out of healthcare. And it was to everybody's benefit to do that because we ended up making good policy decisions." At the 
same time, he added that he was able to use the Centre as a resource to "politically neutralize" his critics by inviting the opposition, the media and the public to meet with the researchers.

This close working relationship did not mean that MCHP researchers supported the party in power, as pointed out by Dr. Norman Frohlich, a long-term research associate and political scientist with Treasury Board experience. He explained that the researchers' role was to provide policy support in the form of clearly articulated research results rather than policy advice. Avoiding policy recommendations was a way to protect the public's perception of the Centre as independent by keeping MCHP distinct from the government of the day. Tom Carson, a deputy minister who worked with about 20 ministers, recommended annual presentations to all caucuses and developing relationships with a policy adviser in each political party. He also stressed political neutrality: "It's absolutely important that the Centre never be seen as being more supportive of one party than another. That's death."

Maynard said working with the Centre marked a huge change in the way government did business. He said that despite sometimes uncomfortable results, the Centre survived years of constraint and several changes in government because its research was helpful, both for determining policy and for defending decisions.

In retrospect, the actual founding of the Manitoba Centre for Health Policy and Evaluation, as it was initially named, seems both remarkable and almost effortless. Orchard said he obtained funding approval on his first request. The Conservative government deserves credit for its willingness to assume the risk of investing in a research centre that could potentially expose flaws in its operations. It was perhaps fortunate for the Centre that early research results supported sound decisions that saved money.

Although the context in which the Centre evolved is unique, the 15 years of research preceding its establishment is an important part of the story. The Rooses' and their colleagues' high standards of research, success in publishing and obtaining grants and their unblemished record of protecting privacy provided a sound foundation for building the Centre. As would be anticipated, these important attributes continued to underpin the success of the Centre over the next 20 years. Table 1 outlines key events after the Centre's founding. Participants discussed these events in ways that conveyed challenges, success factors or both.

\section{Perspectives from Manitoba Health}

The current executive director of the Health Information Branch at Manitoba Health, Deborah Malazdrewicz, who has a 27-year history of working with health information, is well positioned to reflect on the government's relationship with MCHP. She stressed that the Centre's detailed and thorough privacy policies, security audits, technical infrastructure and protocols for researcher access to data give the public a sense of security that their information is being protected, and that this is key to the Centre's sustainability. Manitoba Health strips nominal information from the data sets before supplying them to the Centre, providing fundamental protection.

Malazdrewicz said that the Centre's research has become integral to the healthcare system. In addition to providing important information to assist with decision-making, the reports 
help Manitoba Health better understand healthcare system issues and provide opportunities to develop alliances across departments around program development.

TABLE 1. Key events at the Manitoba Centre for Health Policy: 1990-20 I0

\begin{tabular}{|c|c|}
\hline 1990 & $\begin{array}{l}\text { - August 3: Donald Orchard, Minister of Health, announces the creation of a } \$ 3.5 \text {-million health } \\
\text { research centre to be funded over three years. }\end{array}$ \\
\hline 1991 & $\begin{array}{l}\text { - Noralou Roos is director, MCHPE. } \\
\text { - Leslie Roos is director of the Population Health Research Data Repository. }\end{array}$ \\
\hline 1992 & - Data Dictionary maintained in-house, rather than mainframe computer. \\
\hline 1993 & $\begin{array}{l}\text { - First Rural and Northern Healthcare Day. } \\
\text { - First five-year contract (\$1.9 million per year). } \\
\text { - MCHPE goes online. } \\
\text { - Implementation of Populis - a residence-based data repository linking Manitoba population's health to } \\
\text { healthcare use, economic and social factors. }\end{array}$ \\
\hline 1993-94 & - First fellowships for students conducting research using the database. \\
\hline 1994 & $\begin{array}{l}\text { - Communication firsts: "four-pagers," website, op-eds. } \\
\text { - First external review by Steven Lewis and Maurice McGregor. }\end{array}$ \\
\hline 1995 & $\begin{array}{l}\text { - Cost-cutting by provincial government; MCHPE is protected. } \\
\text { - Medical Care Supplement (Roos and Shapiro 1995). } \\
\text { - Concept Dictionary on Web. }\end{array}$ \\
\hline 1996 & $\begin{array}{l}\text { - Co-directorship starts: Noralou Roos and Charlyn Black. } \\
\text { - Charlyn Black uses premature mortality ratio (PMR) to order graphs and data. } \\
\text { - First website project: "Health Reform in Three Provinces." }\end{array}$ \\
\hline 1997 & $\begin{array}{l}\text { - Six-month government audit. } \\
\text { - Personal Health Information Act (PHIA) legislation passed. }\end{array}$ \\
\hline 1998 & - New five-year contract, now renewable every three years. \\
\hline 1999 & $\begin{array}{l}\text { - Continuity with change of government. } \\
\text { - Interactive format introduced for Rural and Northern Healthcare Day. } \\
\text { - Medical Care Supplement (Roos and Shapiro 1999). } \\
\text { - Canadian Foundation for Innovation (CFI) grant: Data Infrastructure for Improving Health and Human } \\
\text { Capital to fund Brodie Centre, acquisition of new data sets ( } \$ 2.7 \text { million over five years). }\end{array}$ \\
\hline 2000 & - Second review by John Hamerton, Greg Stoddart and Michael Dector. \\
\hline
\end{tabular}

Second 10 Years: Manitoba Centre for Health Policy (MCHP)
2001
- New name: Manitoba Centre for Health Policy.
- The Need to Know Team is funded.
- MCHP awarded Health Services Research Advancement Award by Canadian Health Services Research Foundation.
- October I: First day in new premises; merging two campuses to form Brodie Centre.
- November 2: Grand opening of state-of-the-art data laboratory at Brodie site. 
TABLE 1. Continued

\begin{tabular}{|c|c|}
\hline 2002 & $\begin{array}{l}\text { - Healthcare Management Forum Supplement (Lix 2002). } \\
\text { - Canadian Journal of Public Health supplement (Brownell et al. 2002). } \\
\text { - Data acquired from Family Services and Education. }\end{array}$ \\
\hline 2003 & $\begin{array}{l}\text { - First Manitoba Health Day. } \\
\text { - First Winnipeg Regional Health Authority Day. } \\
\text { - Royal Bank of Canada grant to research children's health (\$750,000 over five years). } \\
\text { - Evelyn Shapiro Award for Health Services Research established. } \\
\text { - January } 2003 \text { to May 2004: Leadership model experiment: co-acting, co-directors. }\end{array}$ \\
\hline 2004 & $\begin{array}{l}\text { - May } 3 \text { I: Noralou Roos steps down as director. } \\
\text { - June } 2004 \text { - June 2005: Patricia Martens is appointed acting director; implements new organizational } \\
\text { structure. }\end{array}$ \\
\hline 2005 & $\begin{array}{l}\text { - Canadian Journal of Public Health supplement (Martens et al. 2005). } \\
\text { - Canadian Journal on Aging supplement (Menec 2005). } \\
\text { - June } 2005 \text { to date: Patricia Martens is director. } \\
\text { - Lupina Foundation grant to support Web-based research knowledge translation through Concept } \\
\text { Dictionary (started in 1990; } \$ 625,000) \text {. } \\
\text { - Patricia Martens, MCHP and The Need to Know Team awarded Canadian Institutes for Health } \\
\text { Research (CIHR) Knowledge Translation Award. } \\
\text { - Third external review by Jonathan Lomas, John Horne and Kevin Kavanagh. }\end{array}$ \\
\hline 2006 & - ClHR report, Privacy Best Practices for Secondary Data Use (Collins et al. 2006). \\
\hline 2007 & $\begin{array}{l}\text { - Les Roos steps down as director of Repository. } \\
\text { - Contract renewed at } \$ 2.35 \text { million a year; first increase }(\$ 495,000) \text { in } 13 \text { years. } \\
\text { - Current strategic plan adopted. }\end{array}$ \\
\hline 2008 & - Treasury Board of Manitoba commissions Steven Lewis to review MCHP impact (Lewis et al. 2009). \\
\hline 2009 & $\begin{array}{l}\text { - CFI grant, "The Manitoba Centre for Health Policy's LEADERS Initiative: Leading-Edge Access and } \\
\text { Data Enhancement Research Strategy" to set up pilot for Repository Access Sites (RAS) and additional } \\
\text { data sets (\$3.6 million). }\end{array}$ \\
\hline 2010 & - March 8-9: MCHP 20th Anniversary Conference: Going for the Gold. \\
\hline
\end{tabular}

Source: Adapted from table presented in The Story of the Manitoba Centre for Health Policy (Marchessault 20 I 0).

Malazdrewicz stressed the importance of the relationship between the Centre and the deputies and ministers: "Transparency and open dialogue has allowed us to have difficult or challenging conversations if necessary, whether it's around a particular deliverable or sustainability of funding to the Centre." She added, "It's all about the relationships and open communication.... And that's hard to get sometimes."

Malazdrewicz said the Centre faced a major challenge several years ago when the Treasury Board questioned whether continued investment in the Centre's research was providing adequate return on investment (ROI). The resulting review listed MCHP's numerous positive impacts, including "reputation, research revenues and productivity, varying influence on policy and system management, and a major cultural and intellectual influence on the Manitoba environment. The quantifiable ROI from research grants alone is close to $200 \%$, but the real impact is likely to be far greater" (Lewis et al. 2009: A37). 
The Centre also survived an earlier funding crisis. Dr. John Wade, who was the deputy minister of health in 1995, credited the Centre's placement within the university and strong support from influential people within government, naming four ministers and deputy ministers. Consequently, he said, the Centre "was maintained through the biggest cost cutting weve ever gone through."

Both Malazdrewicz and Louis Barré, who was director of health information management for 11 years prior to Malazdrewicz's appointment, discussed the involvement of five ministers and five deputies in a recent expansion of funding. Both stressed the Centre staff's commitment to producing high-quality research that met departmental needs as well as extensive efforts they and the Centre's directors made to keep people within government well informed.

Barré said the work the department did to support the Centre included transferring data files, establishing the annual research agenda, conducting briefings for report releases, and maintaining relationships with data providers, users and Centre staff. He said that in many respects, greater effort is required now than previously as contracts have become more complex due to privacy legislation and the expanded scope of engagement with the increase in data sets necessitating negotiations and feedback with multiple departments.

Malazdrewicz suggested that an appreciation for evidence-informed decision-making has spread throughout Manitoba. She credited Dr. Patricia Martens, MCHP's current director, the larger research community and funding bodies such as the Canadian Institutes of Health Research (CIHR) and the Canadian Health Services Research Foundation (CHSRF) for their promotion of knowledge translation. She specifically mentioned the Rural and Northern Healthcare Days and The Need to Know Team for foundational work with small regions.

Barré pointed out that the Centre researchers' external grant funding provides additional benefit to the province. He particularly stressed that the focused policy-based research using local data to address issues of local interest stimulates engagement and increases its relevance and likelihood of use throughout the province. In particular, the smaller rural RHAs find the training and information support invaluable in their regional planning process. Barré described the partnership approach to research problems: "The research that the Centre does about Manitoba is real to the Manitoba audience.... There's a big difference when the focus of the research is local, and local people have been part of defining, executing and acting on the research. That relationship is a really important piece of it."

\section{Lessons Learned: 1991-2010}

Many interviewees said that the Centre's success was due to the people who work there leaders and team members with research proficiency but also the ability and willingness to work as partners with multiple stakeholders. They also remarked that stable, long-term funding was a necessary foundation for achieving these goals.

\section{ADEQUATE AND STABLE FUNDING}

Several interviewees saw government support of a research centre as bypassing the peer review system and creating resentment outside the unit. However, they also said that core fund- 
ing was essential to the timeliness of policy-relevant research. Some expressed doubts that these projects could be done through competitive grants. Manitoba Health's initial funding was sufficiently generous to enable setting up sound infrastructure. The first contract, for example, allowed the founders time to become knowledgeable about newly received data sets. Infrastructure costs continue, as maintaining the dozens of databases now requires extensive time and effort. Adequate and stable funding is needed to attract and retain highly qualified staff, essential to maintaining scholarship standards and academic credibility. Most years the Centre has been able to obtain additional grant funding to match that received from the Manitoba government. Base funding sufficient to support efforts to bring in other sources of revenue have been important to this success.

Nevertheless, there was a 13-year period with no increase in funding levels that created a tense and clearly problematic situation as staffing roughly quadrupled over the same period. In an effort to improve the stability of financial support from government contracts, especially important to job security, the Centre has had five-year contracts with negotiations initiated three years into the contract. If negotiations are straightforward, another five-year contract is put in place at the end of three years, but should the contract require more complex changes, including the renegotiation of funding or updated legislative considerations, the old contract covers the remaining two years.

It is clear that the Centre would not succeed without the significant amount of work done at Manitoba Health to support MCHP efforts as discussed above. This work represents an administrative, financial and political commitment from the Manitoba government.

\section{RECRUIT AND RETAIN GOOD PEOPLE}

The Centre's reputation is a factor in attracting and retaining researchers, important given increased competition for researchers by similar centres elsewhere. The Centre's location in a relatively small city makes recruitment difficult. However, when it comes to retention of technical staff, this situation is advantageous because there is little nearby competition.

MCHP has a strong record in retaining staff. More than $40 \%$ of the original staff of 14 still worked at the Centre as of winter 2009 (Rach 2009). Approximately half of the current 60 full- and part-time employees have been with the Centre for 10 years or longer. Staff cited interesting and challenging projects with noticeable policy impact (which they found gratifying), a lot of autonomy, flexible hours, encouragement for a good work-life balance and the use of the lunchroom and celebratory events to promote bonding as contributing to their satisfaction. Appreciation was expressed for efforts to recognize individuals' contributions, to support learning and taking on new initiatives and to increase remuneration where appropriate and feasible. Frequent staff meetings and retreats were instituted when MCHP underwent major change, as for example when the two campuses merged in 2000, necessitating the blending of two very different work cultures.

Research scientists at the Centre described their work environment as collaborative and supportive. The assigned deliverables come with resources, including a research coordinator and programmer. Weekly meetings bring together experienced researchers to assist with 
challenges encountered from conception through writing up results for submission to peerreviewed journals. For new researchers, such massive support has obvious advantages for their careers and for the Centre's continued ability to attract funding.

Several participants commented that it takes a special kind of person to work at the Centre. Being personable with good communication skills was considered as important as having technical ability, given the emphasis on knowledge translation and sustaining relationships with stakeholders. Directors at the Centre, in particular, needed to be comfortable in both the academic and policy environments.

\section{STRONG LEADERSHIP}

Leadership is ultimately about motivating people to work together to accomplish goals. Great respect was expressed for both the past and current directors for their commitment to the health of Manitobans and the extensive time and energy they have devoted to communication with government and throughout the province. Both the current and past leadership actively support others to make use of administrative data for research purposes through setting up Remote Access Sites, Web-based resources and consulting locally, nationally and internationally. Interviewees described the directors as effective in representing the Centre to the external world and nurturing multiple relationships that stand the organization in good stead when support is needed.

Foremost among these groups is Manitoba Health, the core funder. Meeting the government's need for policy-relevant research is necessary but insufficient. MCHP's director meets with the Manitoba Health director biweekly and with the deputy minister of health every six to eight weeks to ensure mutual understanding. Established processes facilitate joint collaboration on research - from the selection of projects, to advising on research context, to broad dissemination of research results. The process is widely recognized as demanding, with participants within government and the Centre expressing appreciation for one another's support of the partnership. Managers from both areas work to keep people throughout the government, from high-level administrators to healthcare workers, informed about the benefits of MCHP research. This approach creates well-informed advocates, useful, for example, when the government changes.

As already mentioned, MCHP researchers are available to and brief the opposition as well as the party in power. The Centre also releases its reports to the public through press releases and reader-friendly four-page summaries of its research results, and again, researchers are available to discuss these results with reporters.

For over a decade, the Centre has implemented interactive workshops with regional planning teams. These knowledge translation events have been mutually beneficial, as the researchers learn more about programs and program people learn more about research. These workshops evolved into a genuine partnership when The Need to Know Team collaboration was funded in 2001 by CIHR's Canadian Alliance for Health Research program. This award-winning knowledge translation project involved MCHP researchers and data analysts, decision-makers and planners from Manitoba's 11 RHAs and Manitoba Health throughout the research process from the development of the research questions through ensuring use of the results. The team works collaboratively on research, capacity-building for all partners and 
knowledge translation. The project has fostered strong relationships perceived as important to the Centre's survival through difficult economic times. Regional healthcare leaders have indicated to the government that the Centre's research is indispensable to their planning processes.

\section{BUILDING PARTNERSHIPS AND NURTURING RELATIONSHIPS}

At MCHP's 20th anniversary conference, Steven Lewis remarked that the Centre's success depended on its "pedestrian but ground-breaking" nurturing of relationships. Discussion of relationships came up, often repeatedly, in virtually all interviews, as for example in the following comments: "That relationship piece with government is so critically important" (MCHP manager); "Relationship management is a huge part of what it takes to make this work" (Manitoba Health manager); "The relationship the Centre has established throughout the province has been truly phenomenal" (external researcher).

Such comments suggest consensus on the importance of relationships. People talked about developing relationships at multiple levels - with politicians, with senior administrators, with data providers, between programmers in the government and in the Centre, with RHAs, physicians, other researchers, the media, the academic community and more. Participants mentioned the importance of trust, good communication skills and the ability to listen and respond to the needs of different constituencies. Many noted that relationships must be nurtured on a continual basis, and some commented that the Centre has had more than 20 years to develop meaningful relationships.

While most participants emphasized the care taken to ensure high-quality relationships, some referred to partnerships. In fact, as David Orchard described it, his original vision was based on a university-government partnership model. And Brian Postl, chair of MCHP's board, also said that keeping partnerships alive was the key to success but a continuing challenge.

Partnerships are close and cooperative relationships with shared responsibility and accountability for achieving goals. Much of the interview content about the Centre's relationship with Manitoba Health and The Need to Know Team reflect principles that the Community-Campus Partnerships for Health (CCPH 2010) has outlined as essential to authentic university-community partnerships. These principles stress the relationship among partners. The list includes such characteristics as mutual trust, respect, genuineness and commitment; the ongoing prioritization of clear and open communication among partners and efforts to understand one another's needs and interests; continuous feedback to stakeholders; and efforts at capacity-building by all partners.

Much of this seems obvious. However, successful partnerships are difficult to accomplish (CCPH 2010). MCHP's story involves several successful partnerships, and these have been an integral part of its success and longevity.

\section{Strengths and limitations}

Selecting interviewees in consultation with MCHP managers may have introduced a positive bias; however, it also ensured that participants were knowledgeable about MCHP's history. I selected participants to provide perspectives from a cross-section of former and current 
MCHP employees, and personnel from government and external university departments. I also actively searched for critical comments and tried to incorporate the results in a way that respected the tone of participants' discussions. The use of multiple sources and interviews allowed cross-validation of some findings.

\section{Conclusions}

The confluence of many necessary and enabling factors that allowed the Centre to become established is striking and included:

- The existence of the MHSC electronic hospital and physician records.

+ The willingness of MHSC staff to support external research using these data.

- The Rooses' pioneering use of administrative record linkage for more than a decade with established international reputations in health services and population health research.

- The social context that stimulated interest in population health.

- Support from strong leaders in academia, government and respected national organizations.

- An environment of fiscal restraint in the late 1980s that prompted the government's search for evidence for decision-making in its most costly area - health.

These factors were mentioned as significant in prompting the Manitoba government to initiate discussions that eventually resulted in MCHP's establishment in 1991. While some components of this initial context are unique, other factors indicate generalizable lessons for sustainability. The arm's-length relationship with government and guarantees of academic freedom built into the first contract safeguard the Centre's credibility. Credibility is essential to its usefulness, and along with the presence of powerful advocates, viewed as key to longevity. A strong track record combined with continued excellence in scholarship, meticulous protection of privacy, stable funding, incremental growth of database resources, teamwork, leadership and a partnership approach with an emphasis on nurturing relationships were highlighted as important to sustainability.

MCHP has succeeded in making its research relevant nationally and internationally, simultaneously demonstrating that using local administrative data to address specific research questions is of lasting value to the local community and the provincial government.

\section{ACKNOWLEDGEMENTS}

I thank Patricia Martens, Mark Smith, Alan Katz, Paulette Collins and Carole Ouelette (the executive team) for concept and guidance; Theresa Daniuk for finding documents and people; Shannon Lussier and Mya Kraft for tracking down documents relating to the founding directors; Kathy Bell for checking departmental files and reviewing Council meetings for MCHPrelated reports; Angela Bailly for editorial assistance; Jundong Song for technical assistance; Ollie Schroeder and Tina Marchessault for transcribing audio records; and current staff who provided comments and feedback and were supportive throughout the project. 
I especially thank the research participants: Louis Barré, Charlyn Black, Tom Carson, Norman Frohlich, Paul Henteleff, Alan Katz, Deborah Malazdrewicz, Patricia Martens, Arthur Mauro, Frank Maynard, Cam Mustard, Fraser Mustard, Arnold Naimark, Pat Nicol, Donald Orchard, Carole Ouelette, Brian Postl, Leslie Roos, Noralou Roos, Dean Sandham, Evelyn Shapiro, John Wade and eight anonymous participants.

The Lupina Foundation funded this research project.

Correspondence may be directed to: Gail Marchessault, PhD, Qualitative Health Researcher/ Writer, 604 Strathcona St., Winnipeg, MB R3G 3E7; tel.: 204-774-4637; e-mail: marchess@ ms.umanitoba.ca.

\section{REFERENCES}

Baxter, P. and S. Jack. 2008. “Qualitative Case Study Methodology: Study Design and Implementation for Novice Researchers." The Qualitative Report 13(4): 544-59. Retrieved December 20, 2010. <http://www.nova.edu/ssss/ QR/QR13-4/baxter.pdf>.

Bowen, S., P. Martens and The Need to Know Team. 2005. “Demystifying Knowledge Translation: Learning from the Community." Journal of Health Services Research and Policy 10(4): 203-11.

Brownell, M., P.J. Martens and A. Kozyrskyj, eds. 2002."The Canadian Journal of Public Health's Special Supplement: Improving Children's Health: How Population-Based Research Can Inform Policy - The Manitoba Experience." Canadian Journal of Public Health 93(2 Suppl.): S1-S80.

Campbell, C. 1990 (August 4). “Casino Cash to Finance Health Centre.” The Winnipeg Sun.

Collins, P.K., P.M. Slaughter, N. Roos, K.M. Weisbaum, M. Hirtle, J.I. Williams, P. Martens and A. Laupacis. 2006. Harmonizing Research E Privacy: Standards for a Collaborative Future. Privacy Best Practices for Secondary Data Use (SDU) Doc 10: Executive Summary. Ottawa: Canadian Institutes of Health Research.

Community-Campus Partnerships for Health (CCPH). 2010. Principles of Good Community-Campus Partnerships Adopted by the CCPH Board of Directors, October 2006. Seattle: University of Washington. Retrieved December 20, 2010. <http://depts.washington.edu.proxy1.lib.umanitoba.ca/ccph/principles.html\#principles>.

Lewis, S., P.J. Martens and L. Barré. 2009. “Estimating the Return on Investment from Health Services Research: A Theoretical and Empirical Analysis." In Panel on Return on Investment in Health Research. Appendices - Making an Impact: A Preferred Framework and Indicators to Measure Returns on Investment in Health Research. Ottawa: Canadian Academy of Health Sciences. A-21-A-42. Retrieved December 20, 2010. <http://www.cahs-acss.ca/e/ pdfs/ROI_Appendices.pdf>.

Lix, L.M., ed. 2002."The Healthcare Management Forum Supplement: Monitoring the Acute Care Sector: Assessing Key Measures and Trends." Healthcare Management Forum 15(4 Suppl.): 1-66.

Manitoba Centre for Health Policy (MCHP). 2007a. “Message from the Director." Annual Report 2006/07. Winnipeg: Author.

Manitoba Centre for Health Policy (MCHP). 2007b. "Visitors." Annual Report 2006/07. Winnipeg: Author. Manitoba Centre for Health Policy (MCHP). 2008. “Visitors.” Annual Report 2007/08. Winnipeg: Author. Manitoba Centre for Health Policy (MCHP). 2010. MCHP Concept Dictionary and Glossary. Retrieved December 20,2010. <http://umanitoba.ca/faculties/medicine/units/community_health_sciences/departmental_units/ $\mathrm{mchp} /$ resources/concept_dictionary.html $>$.

Marchessault, G. 2010. The Story of the Manitoba Centre for Health Policy. Winnipeg: Manitoba Centre for Health Policy. Retrieved December 20, 2010. <http://umanitoba.ca/faculties/medicine/units/mchp/media/Story_of_ MCHP.pdf>.

Martens, P. 2008 (January 31). “The Manitoba Centre for Health Policy (MCHP): Update.” Presentation to MCHP. 


\section{The Manitoba Centre for Health Policy}

Martens, P.J., K. Avery Kinew, K. Ten Fingers and L. Jebamani, eds. 2005. "The Canadian Journal of Public Health's Special Supplement: Aboriginal Health Research and Policy: First Nations-University Collaboration in Manitoba." Canadian Journal of Public Health 96(Suppl. 1): S1-S63.

Maynard, F. and A. Naimark. 1991. An Agreement for the Establishment and Funding of a Manitoba Centre for Health Policy and Evaluation dated February 4, 1991 between the Government of Manitoba and the University of Manitoba. Unpublished contract.

Menec, V., ed. 2005. “The Canadian Journal on Aging Supplement: Health and Health Care Use Among Older Adults: Using Population-Based Information Systems to Inform Policy in Manitoba." Canadian Journal on Aging 24(Suppl. 1): 1-172.

Patton, M.Q. 2002. Qualitative Research and Evaluation Methods (3rd ed.). Thousand Oaks, CA: Sage.

Rach, J. 2009. "Who We Are." CentrePiece: Manitoba Centre for Health Policy Newsletter 20: 8.

Roos, L.L., M. Brownell, L. Lix, N.P. Roos, R. Walld and L. MacWilliam. 2007."From Health Research to Social Research: Privacy, Methods, Approaches." Social Science \& Medicine 66: 117-29.

Roos, N.P. 1999. “Establishing a Population Data-Based Policy Unit.” Medical Care 37(6): JS15-J26.

Roos, N.P., P.D. Henteleff and L.L. Roos Jr. 1977a. “A New Audit Procedure Applied to an Old Question: Is the Frequency of T\&A Justified?" Medical Care 15: 1-18.

Roos, N.P., L.L. Roos Jr. and P.D. Henteleff. 1977b. “Elective Surgical Rates - Do High Rates Mean Lower Standards? Tonsillectomy and Adenoidectomy in Manitoba." New England Journal of Medicine 297: 360-65.

Roos, N.P. and E. Shapiro, eds. 1995. “Medical Care Supplement: Health and Health Care: Experience with a Population-Based Health Information System.” Medical Care 33(12): DS1-DS146.

Roos, N.P. and E. Shapiro, eds. 1999. “Medical Care Supplement: Academics at the Policy Interface: Revisiting the Manitoba Centre for Health Policy and Evaluation and Its Population-Based Health Information System." Medical Care 37(6): JS1-JS308.

Rubin, J. 1979 (November 20). “End to Unneeded Surgery Sought.” Winnipeg Free Press: 1.

Stake, R. 2005. "Qualitative Case Studies." In N. Denzin and Y. Lincoln, eds., The Sage Handbook of Qualitative Research (3rd ed.). Thousand Oaks, CA: Sage. 